\title{
THE PROBLEM OF "ZERO ELEMENTS" IN THE WORKS OF D. I. MENDELEEV. NEUTRON MATTER AS A PRIMARY COSMOLOGICAL AND MODERN DARK MATTER OF THE UNIVERSE
}

\author{
G. B. Ryazantsev ${ }^{1}$, G.K. Lavrenchenko ${ }^{2}$, S. S. Nedovesov ${ }^{3}$ \\ ${ }^{1}$ Lomonosov Moscow State University, Russia, anis-mgu@rambler.ru \\ ${ }^{2}$ Institute Low-Temperature Energy Problems, Odessa, Ukraine, \\ lavrenchenko.g.k.@gmail.com \\ ${ }^{3}$ Taras Shevchenko National University of Kyiv, Ukraine, pc.remont.tk@gmail.com
}

\begin{abstract}
D.I. Mendeleev assumed the existence of elements X ("Newtonium") and Y ("Coronium") in front of hydrogen in the zero group of the periodic system of chemical elements (PS). It should be recalled that Mendeleev was not mistaken in his predictions of new elements. When he applied the periodic law (PL) to analogues of boron, aluminum and silicon, he had complete confidence in success, because everything was obvious to him there. The idea of elements before hydrogen came to him immediately after the opening of the PL, but he published this only before his death. This question haunted him almost his entire creative life. D.I.Mendeleev did not have time to solve this problem, and his students and followers tried to forget it as "erroneous". It should be noted that after D.I.Mendeleev the question of "zero" elements was repeatedly raised by many authors both in the past and in the present centuries, however, for brevity, we only mention the very first and most famous of them: for example, Ernest Rutherford in 1920 and Andreas von Anthropoff in 1926. Anthropoff was the first to propose the term "neutronium" to refer to a hypothetical element with atomic number zero, which he placed at the beginning of the periodic table (PT). At present, neutron matter, like neutron stars, is a recognized reality in astro- and nuclear physics. From the standpoint of general chemistry, a neutron substance can be classified as chemically simple (that is, it cannot be decomposed into simpler ones by chemical means), then the question inevitably arises of the corresponding element and its place in the PS. Based on the logic of the PL - (ordinal number - electric charge) - the ordinal number of neutron matter will correspond to zero, which makes us remember and develop the ideas of Dmitry Ivanovich Mendeleev about the zero group and period. Based on the works of Tamm, Hund and Migdal, the possibility of the stable existence of neutron matter at the micro level, and not
\end{abstract}

only at the macro level, as is now believed in astrophysics, is stated. Neutron matter is considered as the primary cosmological substance, a candidate for dark matter and its production in laboratory conditions on Earth.

Keywords: D.I.Mendeleev, periodic law, newtonium, coronium, neutronium, neutron matter, zero group and period, dark matter.

АНОТАЦІЯ. Д.І.Менделєєв допускав існування елементів-Х ("Ньютоній") і Y ("короній") перед воднем в нульовій групі періодичної системи хімічних елементів (ПС). Слід нагадати, що Менделєєв не помилився у своїх прогнозах нових елементів. Коли він застосував періодичний закон (ПЗ) до аналогам бору, алюмінію і кремнію, у нього була повна впевненість в успіху, тому що там все було очевидно для нього. Ідея ж доводневих елементів з'явилася у нього відразу ж після відкриття ПЗ, але опублікував він це тільки перед своєю кончиною. Це питання переслідувало його практично все творче життя. Д.І.Менделєєв не встиг вирішити цю проблему, а його учні та послідовники постаралися забути ¥ї як "помилкову". Слід зазначити, що після Д.І.Менделєєва питання про "нульові" елементи неодноразово піднімалося багатьма авторами як в минулому, так і в цьому століттях, проте для стислості згадаємо лише найперших i відомих 3 них: наприклад, Ернеста Резерфорда в 1920 році і Андреаса фон Антропоффа в 1926 році. Антропофф першим запропонував термін "нейтроніум" для позначення гіпотетичного елемента 3 атомним номером нуль, який він помістив в початок періодичної таблиці (ПТ). В даний час нейтронна матерія, як і нейтронні зірки, є визнаною реальністю в астро- та ядерній фізиці. Нейтронну речовину 3 
позиції загальної хімії можна класифікувати як хімічно просту (тобто іiі не можна розкласти на простіші хімічними засобами), тоді неминуче постає питання про відповідний йому елемент і його місце в ПС. Виходячи 3 логіки ПЗ - (порядкове число електричний заряд) - порядкове число нейтронної матерії буде відповідати нулю, що змушує згадати і розвинути ідеї Дмитра Івановича Менделєєва про нульову групу і період. На підставі праць Тамма, Хунди i Мигдала стверджується можливість стабільного існування нейтронної речовини на мікрорівні, а не тільки на макрорівні - як зараз вважається в астрофізиці. Розглядається нейтронна речовина в якості первинної космологічної і як кандидат на темну матерію, та іiі отримання в лабораторних умовах на Землі.

Ключові слова: Д. І. Менделєєв, періодичний закон, ньютоній, короній, нейтроній, нейтронна речовина, нульова група і період, темна матерія.

\section{Introduction}

It was previously shown (Ryazantsev et al., 2014, 2016, $2017,2018,2019)$ that neutron matter in our time is a specific physical reality that requires its rightful place in the PS and the study of not only physical, but also chemical, and, possibly, in the near future, engineering and technical properties. A neutron substance, or rather its corresponding element begins (zero period) and ends (supercritical atoms) PS. The neutron substance is given stability already at the micro level by Tamm interaction, and it is stable not only at the macro level (neutron stars) due to gravitational interaction, as is now believed in astrophysics. The possibility of neutronization is shown not only due to gravitational interaction, but also through other mechanisms (supercritical increase in atomic number of elements (Zel'dovich \& Popov, 1971) and condensation of ultracold neutrons (Shapiro, 1976; Ignatovich, 1996), so there is a fundamental possibility of producing neutron matter in terrestrial conditions (Ryazantsev et al., 2017, 2018, 2019). Neutron matter is consistent with the initial concept of PL and PS proposed by Dmitry Ivanovich Mendeleev (Mendeleev, 1934, 1991; Dobrotin et al., 1984).

From the standpoint of general chemistry, a neutron substance can be classified as chemically simple (that is, it cannot be decomposed into simpler substances by chemical means or reduced to allotropic modifications of already known substances), then the question inevitably arises of the corresponding element and its place in the periodic system. Based on the logic of PL - (ordinal number - electric charge) - the ordinal number of neutron matter in the PS will correspond to zero, which makes us recall and develop the ideas of Dmitry Ivanovich Mendeleev about the zero group and period.

D. I. Mendeleev wrote about the elements before hydrogen: "The chosen subject has long occupied my thoughts, but for various reasons I did not want to talk about it, especially because I myself was not quite satisfied with the few clarifications that I considered able to withstand criticism, and I expected everything from the experiments with which I intended to continue my first attempts, answers that were more encouraging in the correctness of the conclusions made. However, the years passed, the more persistent affairs were torn off, and no one touched on the issue that seemed burning to me, so I decided to say in relation to him - what and how I can, without pretending to solve it, at least approximate. "Elements in front of hydrogen inevitably fall into the zero group and are analogues of inert gases. "This position of the argon analogs in the zero group is a strictly logical consequence of understanding the periodic law," - stated D. I. Mendeleev.

$\mathrm{He}$ admitted the existence of elements $\mathrm{X}$ ("Newtonium") and Y ("Coronium") in front of hydrogen in the zero group. It should be recalled that Mendeleev was not mistaken in his predictions of new elements. He wrote: "When I applied the periodic law to the analogs of boron, aluminum and silicon, I was 33 years younger, I lived in the full confidence that sooner or later the foreseen must certainly be justified, because I could see everything there clearly. The excuse came sooner than I could have hoped. I didn't risk it then, now I do. It takes determination. It came when I saw the radioactive phenomena ... and when I realized that it was impossible for me to postpone and that perhaps my imperfect thoughts will lead someone to a path more correct than the possible one that seems to my failing vision."

D. I. Mendeleev did not have time to solve this problem, and his students and followers tried to forget this topic as "erroneous". Modern knowledge of neutron stars and neutron matter persistently compels to recall his ideas about elements in front of hydrogen and to affirm the truth of his ingenious foresight, which is more than 100 years ahead of the natural sciences of his time.

\section{Stability of neutron matter}

In neutron matter, due to its size (larger than the total absorption layer), the electron emitted during decay is captured by the remaining protons, which, in turn, are converted into neutrons, due to which the dynamic equilibrium of the system is maintained. In fact, this corresponds to both the theory of Igor Evgenievich Tamm (1975), which he put forward in his time (1934) to explain the mechanism of nuclear forces for ordinary nuclei, and the ideas of Frederick Hund (1936). It should be noted that the theory of I.E.Tamm was not satisfactory for ordinary atoms (but he himself valued his "unsuccessful" theory of nuclear forces more than the Nobel work on Cherenkov radiation and considered his best theoretical achievement), but it is consistent and can be realized for neutron matter of an appropriate scale (200-300 and more femtometers), giving it additional stability.

In strongly interacting systems, there are many virtual particles and all kinds of interactions that are allowed for invariance considerations are realized. So, in our opinion, the "original" theory of Igor Tamm's $\beta$-nuclear forces (lepton exchange between nucleons), and not just its modification by Hideki Yukawa ( $\pi$-nucleon exchange), is still awaiting recognition (because besides the meson cloud around the nucleon, of course, there are other particles) and 
"dominates" the neutron matter of the Universe, ensuring its stability and wide spatial distribution.

An initial study of this problem was also given by Frederick Hund (1936) in the first microscopic description of the equation of state of nuclear matter in beta equilibrium in the article "Substance at very high pressures and temperatures", only if Tamm has virtual electrons, Hund implements beta equilibrium completely real particles, but most importantly, both mechanisms contribute to the stability of supercritical nuclear matter, and in strongly interacting systems there is no fundamental difference between virtual and real particles.

It is the additional interaction due to nuclear $\beta$-forces that gives stability to neutron matter already at the micro level, and not only at the macro level due to gravitational interaction, as is now considered in astrophysics!

The possibility of the existence of a super dense neutron nucleus was also considered in the work of A. B. Migdal (1983) "Theory of finite Fermi systems and properties of atomic nuclei" in the section: "Application of Theory of finite Fermi systems in nuclear physics". Migdal considered: "... neutron nuclei can be stable with respect to beta decay and fission, with $Z<<N$ and $N>10^{3}-10^{5}$. Such nuclei could be observed in cosmic rays in the form of large fragments." A. B. Migdal proposed to search for neutron nuclei in the form of exotic traces in photographic emulsions after exposure to cosmic rays.

The theories of Tamm, Hund and Migdal admit the stable existence of hyperheavy neutron nuclei at $\mathrm{Z} \gg 175, \mathrm{~N}>$ $10^{3}-10^{5}$ and sizes of 200-300 and more femtometers.

Nevertheless, it was widely believed that the minimum mass for the stable existence of a neutron object is 0.1 of the mass of the Sun (Potekhin, 2010). It is believed that the equations of state used in this case are based on rich (?). Supposedly experimental material and therefore give a fairly accurate value of the minimum mass. The very fact of the existence of a minimum neutron star mass is justified by the fact that at low densities neutrons, due to susceptibility to beta decay, cannot be the predominant component of matter, and the high neutron density in them is ensured only by gravitational interaction.

Most models of the structure of neutron stars were based on the solution of the Tolman-Oppenheimer-Volkov equation (Potekhin, 2010). Currently, there are several dozen models extending from the so-called "soft" equations of state (derived from models in which, at densities of the order of the nuclear, the average interaction energy corresponds to attraction) to rigid equations of state (obtained for models in which even at densities below the nuclear there is repulsion). Since various models corresponding to different equations of state lead to a rather wide range of parameters characterizing a neutron star, one would hope that an exact determination of such parameters would make it possible to specify the very equation of state of neutron matter, the very nature of the internucleon interaction.

Unfortunately, to date, it has not been possible to obtain reliable estimates of even the basic characteristics of neutron stars. So, the accuracy in determining the radius $\mathrm{R}$ is on average $50-100 \%$. To date, the equation of state has not been obtained in the framework of quantum chromodynamics. Thus, the minimum mass of a neutron star considered equal to 0.1 of the mass of the Sun is obtained from extremely approximate equations with an error of $100 \%$ or more, as indicated in many works on this subject, nevertheless, this number is widely replicated. Based on the conclusions from the theories of Tamm, Hund and Migdal, we can expect a stable existence of microscopic neutron objects $\left(\mathrm{Z}>>175, \mathrm{~N}>10^{3}-10^{5}\right)$ and neutron stars with a mass of less than 0.1 of the Sun.

The author of the very concept of neutron stars Fritz Zwicke (nuclear "goblins" Zwicke (1958) wrote about the possibility of the existence of neutron objects of much smaller sizes $(3-10 \mathrm{~m})$ under certain conditions. He believed that further analysis of matter nuclear density is important not only for our understanding of eruptions in stars, from ordinary flares of stars to supernovae, but it also promises to radically change some of the current ideas on the formation of elements in the theory of evolution of the Universe.

The question of the possibility of obtaining neutron matter under laboratory conditions on Earth is partly a rhetorical one. The fact is that two aspects must be distinguished: mono- (ultracold neutrons (Shapiro, 1976) and polyneutron (similar to cosmic space) matter. As for mononeutron matter, it has long been obtained under terrestrial conditions, although it is not stable (Ignatovich, 1996). The question of obtaining a poly-neutron substance remains to be solved in the near future (Ryazantsev, 2018). The situation is now similar to that in the late 30 s of the last century, when a breakthrough was made in the mastery of nuclear energy, although very many doubted the possibility of this.

\section{Neutrons condensation}

It should be noted that Georgy Antonovich Gamov (1946) first spoke about the condensation of cold neutrons. This idea is rarely mentioned, which over time has found application in the theory of neutron stars. G.A.Gamow in the late 30 s of the last century showed that when a neutron gas is compressed, a new superdense state of matter arises. Gamow's main hypothesis: "We can anticipate that neutrons forming this comparatively cold cloud were gradually coagulating into larger and larger neutral complexes ...".

In further development, the theory of the initial cold Universe was rejected and with it the idea of neutron condensation was forgotten. However, is this true? Neutron condensation is possible not only at low temperatures (ultracold neutrons), but also at ultrahigh pressure at temperatures below critical. In the theory of the Big Bang of a hot Universe, nucleon formation begins at about $\mathrm{t}=10^{-5} \mathrm{~s}$, temperature $\mathrm{T}=10^{12} \mathrm{~K}$, and particle energy $\mathrm{E}=0.1 \mathrm{GeV}$. In this case, protons and neutrons are implied, but for some reason, mainly only protons are considered for possible thermonuclear fusion. Although, if you calculate the density of matter at this moment, then it exceeds the density of a neutron star. That is, under these conditions, the overwhelming majority of nucleons will be in the form of neutrons, not protons, since neutronization conditions are satisfied.

It is more likely to expect the possibility of collective neutron condensation (in the mass, rather than sequential 
addition of individual neutrons, as suggested by Gamov and co-workers) upon reaching a critical temperature (which is an energetically more favorable process (Ryazantsev, 2017) than thermonuclear fusion from a minimum number of protons in those same conditions. Fragmented condensation of neutrons due to quantum gravitational density fluctuations occurs with the release of additional energy, which enhances the formation of hyperheavy stable neutron nuclei, which are the source of nonrelativistic dark matter (neutrality, femto, pico and nanoscale sizes, relict cooling makes it difficult for us to detection). The observable part of the Universe is formed from the residual part of protons and subsequently decaying single neutrons and unstable fragments of neutron matter (with $\mathrm{Z}>175$, but $\mathrm{N}<10^{3}-10^{5}$ ).

Usually on Earth we deal with neutron radiation of various energies, but not with neutron matter. This was until 1968, when an experiment was conducted at the Laboratory of Neutron Physics, led by Corresponding Member of the USSR Academy of Sciences Fedor Lvovich Shapiro (1976), in which the phenomenon of confinement of very slow neutrons in vessels predicted by academician Yakov Borisovich Zel'dovich (Ignatovich, 1996) was first observed. The behavior of neutrons held in evacuated vessels resembles the behavior of a very rarefied gas in a vessel. Such neutrons are called ultracold (UCN). The retention of UCNs in vessels attracts researchers with the opportunity (in comparison with a single neutron passage through the experimental volume) to observe this elementary particle longer in the experimental setup, which gives a significant increase in the sensitivity and accuracy of experiments on the interaction of neutrons with fields and matter.

For example, the use of UCNs made it possible to significantly lower the limit of existence of the electric dipole moment of the neutron necessary to verify the law of conservation of time parity; more accurately measure the lifetime of a free neutron before $\beta$-decay. The most important feature of UCNs is that they behave not as radiation, but as a substance, and it is possible to work with them as a substance similar to a discharged inert gas. Moreover, it is possible to study both physical and its chemical properties. Physical properties are already being studied, but UCN chemistry, it seems, does not even raise the question, because by default it seems somehow obvious that they should be similar to inert gases. This seems to be true, but now we already know well that inert gases, albeit with difficulty, enter into chemical reactions and form, even if not stable, but chemical compounds. Could this happen to UCN? Based on the fact that Chemistry is only the interaction of electron shells of atoms, as many believe, a categorical negative answer follows. But, if Chemistry is understood more broadly, in general, the ability of micro (nano, pico or even femto) objects to interact and form relatively stable compounds, then why not?

Yes, neutrons do not have an electric charge and free electrons, so all ideas about possible classical chemical bonds (ionic, covalent, etc.) immediately disappear unambiguously. But, neutrons have precisely the magnetic moment and possibly the electric dipole moment (the essential role of which is well known in chemistry), can this not serve as the ability to interact with other objects and form though not stable, but still observable compounds? For example, the interaction of UCNs with molecules of substances with an odd number of electrons is quite possible, and an experiment to detect the products of this interaction is quite real (Ryazantsev, 2017).

The development of new sources of UCN is being actively carried out all over the world, some of them are based on the use of solid deuterium at a temperature of 4.5 K (LANL, USA; PSI, Switzerland), while others are based on the accumulation of UCN in superfluid helium (KEKRCNP-TRIUMF, Japan-Canada; ILL, France) (Serebrov et al., 2011). Similar work is intensively carried out in Russia: the Neutron Laboratory at the Joint Institute for Nuclear Research (Dubna) and the St. Petersburg Institute of Nuclear Physics (PNPI). In Gatchina, work is underway to create a high-intensity source of UCN. With its help, they hope to obtain data that will give answers to the most important questions of modern physics. The designed source will make it possible to obtain a flux of ultracold neutrons (UCN) with a density of $10^{4} \mathrm{~cm}^{-3}$, which is many times higher than the maximum densities now achieved (Serebrov et al., 2011). This task - obtaining intense UCN flows - is today considered one of the priorities in neutron physics. A more and more increase in the density of UCNs will inevitably lead to the question of their possible condensation and the production of a condensed neutron substance under laboratory conditions, such as space.

Not so long ago, a decisive breakthrough was made into a new area: a radically new type of matter, the so-called Bose condensates of atoms of matter, was created. Are neutron condensates possible? Condensates whose density and strength will be comparable to the density and strength of atomic nuclei. In other words, how close have they come to the frontier of creating cosmic neutron matter in the laboratory today?

The 2001 Nobel Prize in Physics was awarded to researchers Eric A. Cornell, Wolfgang Ketterle and Carl E. Wieman for obtaining and investigating the properties of the fifth state of matter - the Bose-Einstein condensate, they were able to get the first Bose condensate (Cornell at al., 2003). It was possible to do this using methods developed shortly before this, in addition to cooling particles by laser beams and magnetic field. The Bose condensate of atoms was obtained in a form convenient for research and laboratory analysis. Soon reports of the receipt of Bose condensates of various atoms sprinkled from everywhere. Scientists were greatly encouraged by the fact that Bose condensate plants were relatively inexpensive - experiments were well underway in many countries. Soon, methods were also found for producing Bose condensates of half-integer spin particles, fermions, which include neutrons. In them, particles combine in pairs, then collecting in the Bose condensate. In many properties, neutrons are close to the lightest atoms.

For example, the mass of a neutron is almost equal to the mass of a hydrogen atom, the Bose condensate of which was obtained by Ketterle in 1997. But, unlike atomic Bose condensates, whose natural compression during Bose condensation is an insurmountable obstacle to their electron shells, nothing prevents the compression of the neutron Bose condensate. In such a condensate, UCN gas forms pairs with opposite spins; upon reaching critical density and 
temperature, it spontaneously shrinks to almost nuclear density when nuclear forces come into play, forming a stable state - a condensed neutron substance. If in space a stable polyneutron substance is formed at ultrahigh pressures, then on Earth it will be obtained at ultra-low temperatures with a sufficient concentration of UCNs, which sooner or later researchers will come to receive.

\section{Conclusion}

Thus, neutron matter in our time is a very specific physical reality that urgently requires its rightful place in the PS and the study of not only physical, but also chemical, and possibly in the near future, and engineering properties. A neutron substance, or rather an element corresponding to it, begins (zero period) and ends (supercritical atoms) PS elements. The neutron substance is given stability already at the micro level due to the additional (Tamm, Hund, Migdal) interaction, and not only at the macro level due to gravitational interaction, as is now believed in astrophysics. The possibility of polyneutronization is shown not only due to gravitational interaction, but also by other mechanisms (supercritical increase in the sequence number of elements and condensation of UCNs), thus, there is a fundamental possibility of obtaining neutron matter in Earth conditions (at $\mathrm{Z}>175, \mathrm{~N}>10^{3}-10^{5}$ and the size of $200-300$ or more femtometers). Neutron matter is a necessary link (bridge) from micro to macro and mega-world, from free neutron to neutron stars and black holes. Such an extremely concentrated substance is the thermodynamically and statistically most stable state of matter as such. This substance can be represented as a set of densely packed neutrons, with scattered residual protons and electrons among them.

Now it is believed that almost all chemical elements appeared in the "thermonuclear reactors" of stars and supernovae. The Big Bang prepared only fuel for them: a few of the lightest elements. The lion's share fell on hydrogen, which so far (and by a wide margin) remains the most abundant in the Universe. However, in small amounts, helium, beryllium, and lithium formed at the same time.

Theorists explained with good accuracy why they were formed in one or another quantity. With one exception: the content of lithium in the Universe cannot be predicted by modern models. The isotope of lithium-7 is three times less than that obtained in theory, and lithium- 6 is several orders of magnitude more. This non-docking remains a real headache for cosmology: it is not possible to "fit" the Big Bang model under it, and some suitable explanations call into question the Big Bang itself.

Thus, it is necessary to take into account the possibility of the formation of neutron matter fragments as dark matter (neutrality, femto-, pico- and nano-sizes, relict cooling make them difficult to detect) already at the initial moments of the birth of the Universe, which is the dominant process, and not thermonuclear fusion from initial small amount of protons. Next, the process goes according to the generally accepted scenario.

Neutron matter fits consistently into the original concept of the Periodic Law and the System put forward by Dmitry Ivanovich Mendeleev, the 150th anniversary of which we celebrate this year (Mendeleev, 1934; Ryazantsev et al., 2018).

\section{References}

Cornell E. A., Wieman C.E., Ketterle W.: 2003, UFN, 173, №12, 1319 http://ufn.ru/ru/articles/2003/12/c/.

Dobrotin R.B. et al.: 1984, Letopis' zhizni i deyatel'nosti D.I.Mendeleeva. Ed. Storonkin A.V., L.: Nauka (in Russian).

Gamow G.: 1946, Phys. Rev., 70, 572.

Hund F.: 1936, Ergebnisse der exakten Naturwissenschaften, $15,189$.

Ignatovich V. K.: 1996, UFN, 166, №3, 303.

Mendeleev D. I.: 1934, Sochineniya. L.-M.,T.2 /Eds. A.N.Bakha, B.N.Vyropaeva, I.A.Kablukova et al., L.: Goskhimtekhizdat, 520 s. (in Russian).

MendeleevD.I.: 1991, Granits poznaniya predvidet' nevozmozhno. Sobranie rabot. Ed.: Yu.I. Solov'ev, M. (in Russian).

Migdal A.B.: 1983, Teoriya konechnykh Fermi sistem $i$ svoystva atomnykh yader, M.: Nauka, Glavnaya redaktsiya fiziko-matematicheskoy literatury, 54 p. (in Russian).

Potekhin A.Yu.: 2010, UFN, 180, №12, 1279.

Ryazantsev G. B., Lavrenchenko G. K.: 2014, Tekhnicheskie gazy. №1, 3-10 (in Russian).

Ryazantsev G. B.: 2014, Nauka $i$ zhizn', № 2, 76 http://www.nkj.ru/archive/articles/23734/ (in Russian).

Ryazantsev G. B., Lavrenchenko G. K.: 2016, Tekhnicheskie gazy. №4, 41 (in Russian).

Ryazantsev G.B., Lavrenchenko G.K., Khaskov M.A., Beckman I.N.: 2017, ISINN-24. 24th International Seminar on Interaction of Neutron with Nucle. Dubna, JINR, Russia, 65.

Ryazantsev G.B., Lavrenchenko G.K., Beckman I. N., BuntsevaI. M., Nedovesov S. S.: 2018, Odessa Astron. Publ., 31, 33.

Ryazantsev G.B., Lavrenchenko G.K., Beckman I.N., Buntseva I.M.: 2018, 18-th Gamow Summer School. Odessa, Ukraine, Abstrats, 15.

Ryazantsev G.B., Beckman I.N., Lavrenchenko G.K., BuntsevaI. M., Nedovesov S.S.: 2019, ISINN-26. 26th International Seminar on Interaction of Neutrons with Nuclei. Dubna, JINR, Russia, 37.

Shapiro F.L.: 1976, Sobranie trudov. Moskva: Nauka, 2, 348 (in Russian).

Serebrov A.P. et al.: 2011, Physics Procedia, 17, 251.

Tamm I.E.: 1975, Sobranie nauchnykh trudov, T.1, Nauka, M., 283 (in Russian).

Zel'dovich Ya.B., Popov V.S.: 1971, UFN, 105, 403.

Zwicky F.:1958, Publications of the Astronomical Society of the Pacific, 70, № 416, 506. 